\title{
Does parental expressed emotion moderate genetic effects in ADHD? An exploration using a genome wide association scan.
}

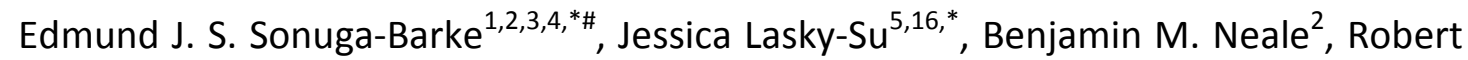
D. Oades ${ }^{6}$, Wai Chen ${ }^{1,2}$, Barbara Franke ${ }^{7,8}$, Jan K. Buitelaar ${ }^{7}$, Tobias Banaschewski ${ }^{9,10}$, Richard P. Ebstein ${ }^{11}$, Michael Gill ${ }^{12}$, Richard J. L. Anney ${ }^{12}$, Ana Miranda ${ }^{13}$, Fernando Mulas $^{17}$, Herbert Roeyers ${ }^{4}$, Aribert Rothenberger ${ }^{9}$, Joseph A. Sergeant ${ }^{14}$, Hans Christoph Steinhausen ${ }^{15}$, Margaret Thompson ${ }^{1}$, Philip Asherson ${ }^{2}$, Stephen V. Faraone ${ }^{5}$

2008 American Journal of Medical Genetics Part B, 147B, 1359-1368.

This is the reformatted manuscript submitted - prior to publication in its final form at DOI: 10.1002/ajmg.b.30860.

1. Developmental Brain-Behaviour Unit, University of Southampton, Southampton, UK.

2. Social Genetic and Developmental Psychiatry Centre, Institute of Psychiatry, University of London, UK.

3. Child Study Center, New York University, USA.

4. Department of Experimental Clinical Psychology, University of Gent, Belgium.

5. Child and Adolescent Psychiatry Research, SUNY Upstate Medical University, Syracuse, New York, USA

6. University Clinic for Child and Adolescent Psychiatry, Essen, Germany.

7. Department of Psychiatry, Radboud University Nijmegen Medical Center, Nijmegen, The Netherlands

8. Department of Human Genetics, Radboud University Nijmegen Medical Center, Nijmegen, The Netherlands

9. Child and Adolescent Psychiatry, University of Göttingen, Göttingen, Germany.

10.Department of Child and Adolescent Psychiatry and Psychotherapy, Central Institute of Mental Health, University of Mannheim, Mannheim, Germany.

11. Herzog Memorial Hospital, Jerusalem, Israel

12.Department of Psychiatry, Trinity Centre for Health Sciences, St. James's Hospital, Dublin, Ireland.

13.Department of Developmental and Educational Psychology, University of Valencia, Spain

14.Vrije Universiteit, De Boelelaan, Amsterdam, The Netherlands

15.Department of Child and Adolescent Psychiatry, University of Zurich, Switzerland.

16.Channing Laboratories, Brigham and Women's Hospital, Boston, MA, USA

17. Neuropediatric Service, Hospital La Fe, University of Valencia, Spain

- These authors contributed equally to this manuscript.

\# Correspondence: Email: ejb3@soton.ac.uk 


\begin{abstract}
Background: Studies of gene $x$ environment (GXE) interaction in ADHD have previously focused on known risk genes for ADHD and environmentally mediated biological risk. Here we use GXE analysis in the context of a genome-wide association scan to identify novel genes whose effects on ADHD symptoms and comorbid conduct disorder are moderated by high maternal expressed emotion (EE).

Method: 600,000 SNPs were genotyped in 958 ADHD proband-parent trios. After applying data cleaning procedures we examined 429,981 autosomal SNPs in 909 family trios. ADHD symptom severity and comorbid conduct disorder was measured using the Parental Account of Childhood Symptoms interview. Maternal criticism and warmth (i.e., EE) were coded by independent observers on comments made during the interview.

Results: No GXE interactions reached genome-wide significance. Nominal effects were found both with and without genetic main effects. For those with genetic main effects 36 uncorrected interaction $p$-values were less than $10^{-5}$ implicating both novel genes as well as some previously supported candidates. These were found equally often for all of the interactions being investigated. The observed interactions in SLC1A1 and NRG3 SNPS represent reasonable candidate genes for further investigation given their previous association with several psychiatric illnesses.

Discussion: We find evidence for the role of EE in moderating the effects of genes on ADHD severity and comorbid conduct disorder, implicating both novel and established candidates. These findings need replicating in larger independent samples.
\end{abstract}

Key Words: ADHD; Gene-by-environment interaction; FBAT; Genome-wide association; Hostility.

\section{INTRODUCTION:}

Behaviour genetic studies using twin and adoption designs provide compelling evidence for a genetic basis to Attention Deficit/Hyperactivity Disorder [Mick and Faraone 2008]. Molecular genetic studies focusing on candidate genes have identified a number of DNA variants showing statistically significant associations with the ADHD diagnosis [Faraone et al., 2005]. The most consistent effects are for variants at or near genes coding for dopamine function [Li et al., 2006]. However, the size of these effects for individual variants is typically very small and even in sum they account for only a small fraction of causal variance. Our recent Genome-Wide Association Scan (GWAS) of ADHD, including 600,000 individual SNPS identified a number of promising new genetic markers of nominal significance, however, no individual associations reached genome-wide significance [Neale et al., submitted]. This genome-wide negative result included SNPs in regions previously supported in candidate gene studies. This result is consistent with the view that ADHD is a highly complex and heterogeneous genetic condition, with multiple genes of very small effect implicated to different degrees across affected individuals.

There are a number of promising approaches to partitioning genetic heterogeneity in ADHD [Thapar et al., 2007]. One approach, involves identifying phenotypic characteristics that define subgroups of patients affected by specific sets of genes so that a more direct mapping of specific genes to disorder can be made [Sonuga-Barke et al., 2008; Caspi et al., 2008; Crosbie et al., 2008]. Identifying alternative ADHD-related phenotypes, defined both a priori (e.g., hyperactiveimpulsive vs. inattentive symptoms) and on empirical grounds using multivariate techniques, proved a useful way of identifying novel genetic candidates in an alternative analysis of the IMAGE GWAS data mentioned above [Lasky-Su et al., submitted; Neale et al., submitted; see 
also Oades, 2002]. Genetic heterogeneity can also be partitioned in terms of variations in environment to which individuals are exposed. Genes interact with environments so that increased liability for a disorder associated with a gene may be seen more for individuals exposed to particular environmental risks [Rutter et al., 2006]. In fact, synergistic interaction of this sort, may mean a significant effect of a particular gene is present only for exposed individuals, with no apparent effect for those unexposed [Caspi et al., 2003; Khan et al., 2003]. In this case, the size of effect of an individual gene would be determined in part by the degree of exposure to the environmental risk operating within the affected population as a whole. This means even quite large genetic effects operating only within sub-populations affected by a specific environmental factor may not reach statistical significance when effects are aggregated across the ADHD population as a whole.

There has recently been considerable interest in gene $x$ environment interactions ( $G x$ E) in ADHD following attempts to better understand the pathogenic mechanisms underpinning the disorder [Thapar et al., 2007]. The focus has been on known candidate genes and environmentally-mediated biological risk factors. For instance, pre-natal exposure to nicotine [e.g., Becker et al., 2008; Khan et al., 2003; Neuman et al., 2007] and alcohol [e.g., Brookes et al., 2006a] have both been shown to interact with variations in dopamine genes to increase the levels of ADHD symptoms. In the current paper we exploit the recent development of high throughput techniques that allow the genotyping of hundreds of thousands of single-nucleotide polymorphisms (SNPs) across the genome combined with new analytical techniques [Vansteelandt, 2008]. This allowed us to identify associations for further study including (i) novel GXE with known and novel genes that also have a nominally significant main effect (with potentially important consequences for models of ADHD pathophysiology) and (ii) $\mathrm{G} \times$ Es that occur even though there are no genetic main effects: $A$ situation suggestive of genetic effects in environmentally defined sub-populations of ADHD children. Like other papers included in this special issue the reported analysis was based on 958 ADHD-parent trios from the International Multicenter ADHD Genetics Project (IMAGE) genotyped on a 600K SNP GWAS as part of the Genetics Analysis Information Network (GAIN)[http://www.fnih.org/GAIN2/home _new.shtml].

The family environment is the focus for the current analyses. ADHD children are exposed to raised levels of negative parent-child relationships, family dysfunction, parenting stress and psychopathology [Johnston and Mash, 2001], effects which seem stronger where ADHD is comorbid with externalizing problems [Pfiffner et al., 2005]. Evidence already exists for $G \times E$ effects on externalizing problems involving the family environment. Pressman and colleagues [Pressman et al. 2006] demonstrated high levels of conflict in the families of children with ADHD and showed that these effects appeared to mediate familial patterns of impairment in siblings. More direct evidence of $G \times E$ effects comes from studies showing that maternal insensitivity is associated with preschool externalizing disorders only in children carrying the 7-repeat allele of DRD4 [Bakermans-Kranenburg and van ljzendoorn, 2006], and that parental warmth was protective for externalizing disorders only in the absence of the 7repeat allele, but only for AfricanAmerican children [Propper et a., 2007].

Expressed emotion (EE) is an important marker of parental negative attitudes and behavior directed towards their children [Vaughn and Leff, 1976]. It incorporates aspects of criticism, hostility or emotional over-involvement and is unusually high in ADHD [Baker et al., 2000; Daley et al., 2003; Psychogiou et al., 2007]. Current 
evidence suggests that EE does not play a main causal role in ADHD but rather that ADHD elicits high levels of EE from some parents [Taylor et al. 1996; Schachar et al., 1987]. However, it remains possible that high EE may affect ADHD levels in a genetic sub-group of ADHD patients perhaps exacerbating already existing problems, increasing the severity of the condition or its persistence into adolescence and adulthood. Furthermore there is good evidence that $\mathrm{EE}$ associated with ADHD is implicated in the emergence of comorbid conduct disorder over time [Taylor et al., 1996]. In an analysis of the IMAGE sample there was a consistent pattern of association between parental criticism and lack of warmth and oppositional defiant and conduct disorder [Psychogiou et al., submitted] an association that was moderated by variations in serotonin and dopamine transporter genes [Sonuga-Barke et al., submitted]. In the current paper we explored the moderating effects of EE on genetic effects for ADHD severity and comorbid conduct problems. Our aim was to identify novel $G X E$ effects. Through this we hoped to illustrate the power of this approach for partitioning genetic heterogeneity and identifying novel genes whose effects may be confined to EE-defined subgroups.

\section{Methods:}

\section{Subjects}

Families were collected by the International Multicenter ADHD Genetics (IMAGE) project. Families were identified through ADHD probands aged 5 to 17 attending outpatient clinics at the data collection sites in Europe and Israel. A total of 958 affected proband-parent trios were initially selected for GWAS. Family members were Caucasians of European origin from Belgium, Germany, Ireland, the Netherlands, Spain, Switzerland, and the United Kingdom, as well as Israel. Of these, 936 probands were initially ascertained as having DSM-IV combined type ADHD. Twenty-two probands who did not meet combined subtype ADHD diagnosis were included because they either met the criteria for the inattentive or hyperactive subtypes, or they missed the DSM-
IV combined type diagnosis by a single item. Since our analysis is primarily based on ADHD diagnosed individuals, we can only generalize our findings to this group of individuals.

\section{Phenotypic Outcome}

Two quantitative traits intended to measure ADHD and conduct disorder (CD) severity were generated as the outcome phenotypes for use in the association analyses using the Parental Account of Childhood Symptom (PACS). The PACS is a reliable, semi-structured interview that measures children's behavior [Taylor et al. 1986a; Taylor et al. 1986b]. The PACS was administered by investigators at each center to the parents of the affected child. There was centralized training for all who administered the PACS and the coding of responses to questions were standardized. Parents were asked to describe their child's symptoms during medication-free periods, both currently and over the past two years. The PACS assesses the DSM-IV symptoms for both $A D H D$ and $C D$ in children and adolescents. The inattentive and hyperactive-impulsive symptoms measured by the PACS for ADHD include: 1) inability to pay attention to details; 2) difficulty with sustained attention in tasks or play activities; 3) listening problems; 4) difficulty following instructions; 5) problems organizing tasks and activities; 6) avoidance or dislike of tasks that require mental effort; 7 ) tendency to lose things like toys, notebooks, or homework; 8) distractibility; and 9) forgetfulness in daily activities, 10) fidgeting or squirming; 11) difficulty remaining seated; 12) restlessness; 13) difficulty playing quietly; 14) always seeming to be "on the go"; 15) excessive talking; 16) blurting out answers before hearing the full question; 17) difficulty waiting for a turn or in line; and 18) problems with interrupting or intruding. The CD symptoms include: 1 ) severity of destructiveness; 2) frequency 
of destructiveness; 3 ) severity of aggressiveness; 4) frequency of aggressiveness; 5) bully; 6) start fights; 7) used weapon; 8) cruel to animals; 9) cruel to people; 10$)$ stay out at night; 11 ) tried to set fire to something; 12 ) run away from home; 13) broken into a building or car; 14) truanted from school; 15) threatened anyone with a gun; 16) mugging, extortion, or robbery; and 17) forced someone into sexual activity. Each symptom is given a value of 0 or 1 to demarcate the absence or presence of the symptom respectively. The total symptom counts for both ADHD and CD were generated by summing over all symptoms, making the maximum symptom count 18 and 17 respectively. The symptom counts for ADHD and $C D$ were used as the phenotypic traits in the GXE analyses.

\section{Environment measures}

Parental Expressed Emotion: Assessment of mothers' and fathers' expressed criticism and warmth was made using codings derived from the Camberwell Family Interview on the basis of parental responses during the clinical assessment. In this analysis, we only used the measures of maternal expressed criticism and warmth, as these variables were more complete. Warmth was assessed by the tone of voice, spontaneity, sympathy, and/or empathy toward the child. A great deal of expressed warmth (0) was coded when there was definite warmth, enthusiasm, interest in, and enjoyment of the child. Quite a lot of demonstration of warmth (1) was coded when there was definite understanding, sympathy, and concern but only limited warmth of tone. Moderate demonstration of warmth (2) was coded when there was a detached and rather clinical approach, with little or no warmth of tone, but moderate understanding, sympathy, and concern. Little warmth (3) was coded when there was only a slight amount of understanding, sympathy, or concern or enthusiasm about or interest in the child or when parents did not display any of the qualities of warmth described above.
Criticism was assessed by statements which criticized or found fault with the child based on tone of voice and critical phases. A lot of expressed criticism (4) was coded when the parent mentioned critical comments indicating that the respondent dislikes, resents, disapproves of, or is angered or annoyed by the child's behavior or characteristics. High criticism was also based on harsh tone of voice, even if the statement did not meet the content criteria. For a statement to be considered critical, the inflection, pitch, and/or rate of speech had to be dramatically different from the baseline. The tone had to strongly indicate resentment and/or anger about the topic being discussed. Quite a lot of expressed criticism (3) was coded when there were indication that the parent did not like or approve of the child's behavior. Some criticism (2) was coded when there were statements of dissatisfaction indicating that the parent was bothered, irritated or upset by the child's behavior or characteristics. Very little expressed criticism (1) and no expressed criticism (0) were coded when there was no evidence during the interview that the parent disapproves or dislikes child's behavior. Inter-rater reliability on these codings has been satisfactory; ranging from .79 to .86 [Schachar et al., 1987]. In order to ensure cross-site consistency within the IMAGE project in measurement and coding of PACS scales including those relating to expressed emotion all interviewers from each site attended a 5-day training course in the UK. The chief investigator at each site attended annual inter-rater reliability exercise and was responsible for reliability in their native site. A mean Kappa coefficient across all sites of 0.88 (range $0.71-1.00$ ) and an average agreement percentage of $96.6 \%$ (range 78.6-1.00) were obtained indicating a substantial level of inter-rater agreement (Chen et al., 2008). 


\section{Genotyping}

Details of the genotyping and data cleaning process were reported elsewhere [Neale et al., submitted]. Briefly, genotyping was performed by Perlegen Sciences using the Perlegen platform. The Perlegen Array uses which has 600,000 tagging SNPs designed to be in high linkage disequilibrium with untyped SNPs for the three HapMap populations. Genotype data cleaning and quality control procedures were done by The National Center for Biotechnology Information (NCBI) using the GAIN QA/QC Software Package (version 0.7.4) developed by Gonçalo Abecasis and Shyam Gopalakrishnan at the University of Michigan. A copy of the software is available by e-mailing gopalakr@ umich.edu or goncalo@umich.edu. Data were removed on the basis of the following quality control metrics: 1) sample genotype call rate < 95\%; 2) gender discrepancy; 3) per-family Mendelian errors $>2 \%$; 4) sample heterozygosity $<32 \%$; 5) genotype call quality score cutoff of > $10 \%$; 6) a combination of SNP call rate and minor allele frequency (MAF) (a) $0.01 \leq$ MAF < 0.05 and call rate $\geq 99 \%$; b) $0.05 \leq \mathrm{MAF}<0.10$ and call rate $\geq 97 \%$; and c) $0.10 \geq \mathrm{MAF}$ and call rate $\geq 95 \%)$; 7) deviation from Hardy-Weinberg equilibrium with a p-value $<0.000001$; and 8 ) duplicate sample discordance. The removal of additional SNPs based on other GAIN samples that was reported in the initial manuscript were not applied to the data presented here [Neale et al., in press].

\section{Statistical Analyses}

We apply the FBAT1-Interaction methodology proposed by Vansteelandt et al. [Vansteelandt et al., 2008] for nuclear families where gene-by-environment interactions can be modeled using SNPs, quantitative phenotypes, and complex exposure variables. Vansteelandt et al.'s [Vansteelandt et al., 2008] method uses causal inference to derive estimating equations that generate an estimate of the main genetic effect, $\beta_{1}$, and the gene-by-environment interaction, $\beta_{2}$ after accounting for the main genetic effect. The general principle behind FBAT-Interaction is that after removing the overall main genetic effect, the phenotype should not depend on the genotypes conditional on the environmental exposure under the null hypothesis. Such a test is therefore valid regardless of the estimate for the main genetic effect. This class of estimates and tests is available in the program PBAT [Lange et al., 2004] [http://biosun1.harvard.edu/ clange/pbat .htm].

Using this methodology we assessed possible SNP-by-environment interactions using the GWAS data. There were two environmental variables, a measure of mother's warmth and mother's criticism, and two quantitative phenotypes, ADHD symptom count and CD symptom count, resulting in four different SNP-byenvironment interaction analyses: 1) Mother's warmth with ADHD symptom count; 2) Mother's warm with $C D$ symptom count; 3 ) Mother's criticism with ADHD symptom count; and 4) Mother's criticism with $C D$ symptom count. These analyses were run looking at additive, dominant, and genetic modes or inheritance. Given that there were four phenotype/environmental exposure combinations and three genetic analyses, in total 12 GWAS were analyzed. The most significant associations are presented.

We also examined the interaction $p$ values for SNPs in a set of pre-specified ADHD candidate genes that was generated by the IMAGE study investigators [Brookes et al., 2006a]: NR4A2, PER2, SLC6A1, DRD3, SLC9A9, HES1, ADRA2C, ADRB2, ADRA1B, DRD1, HTR1E, DDC, STX1A, ADRA1A, NFIL3, ADRA2A, ADRB1, SLC18A2, TPH1, BDNF, FADS1, FADS2, ADRBK1, ARRB1, DRD2, HTR3B, TPH2, SYT1, HTR2A, SLC6A2, ARRB2, PER1, PNMT, CHRNA4, COMT, ADRBK2, and CSNK1E.

When correcting for the overall number of statistical tests, there are two environmental variables, two phenotypes, 
and all of the GWAS SNPs. Given this information, a $\mathrm{p}$-value less than $1.14 \times 10^{-8}$ would achieve genome-wide significance. When considering the candidate genes alone, a significant finding would need to be less than $9.06 \times 10^{-6}$, which corrects for all of the comparisons at all candidate genes and all phenotype/environmental exposures. In this report we display our findings but look to future replications to verify is refute the nominally significant results.

\section{RESULTS:}

After the quality control procedures, 438,784 markers were available for analytic use. The $G x$ $E$ interaction analysis in PBAT cannot analyze sex-linked markers. Consequently, we restricted our statistical analysis to 429,981 autosomal markers. A total of 2803 individuals, 1865 founders and 938 non-founders were included after the cleaning process. Of these individuals, 29 offspring did not have clinical data and/or parental genotypes resulting in 909 individuals used in the analysis. A summary of the sample is listed in table 1

$G \times E$ interaction found in the context of genetic main effects: No SNP achieved genomewide significance, i.e., $p<10^{-8}$. The 37 interaction $\mathrm{p}$-values $<10^{-5}$ are summarized in tables 2 and 3 . Among these association tests, the interaction of SNPs in PIWIL4 and KIF6 and mother's warmth were associated with ADHD symptom count. For CD symptom count, strong interactions between mother's warmth and SNPs in RIT1, ADH1C, SLC6A1, A2BP1, and MFHAS1 were observed. One of these findings is in one of the ADHD candidate genes that had been selected a priori (SLC6A1, the gammaaminobutyric acid transporter). Finally, interactions between SNPs in PPM1K and ZBTB16 and mother's criticism were observed when the $C D$ symptom count was used as the phenotype. For all of these interaction associations, the association $p$-value for the main genetic effect is less than 0.01 .
Table 1:

Descriptive Statistics of the Individuals used in the GWAS analyses (Standard Deviation, SD)

\begin{tabular}{|c|c|}
\hline Number of parents & 1865 \\
\hline Number of children & 938 \\
\hline Number of ADHD diagnosed children & 933 \\
\hline $\begin{array}{l}\text { Gender distribution of the offspring } \\
\text { Male (percent) } \\
\text { Female (percent) }\end{array}$ & $\begin{array}{ll}816 & (86.99) \\
122 & (13.01)\end{array}$ \\
\hline Age among offspring (SD) & $10.88(2.81)$ \\
\hline $\begin{array}{l}\text { Average total number ADHD symptoms (SD) } \\
\text { Average total number of CD symptoms (SD) }\end{array}$ & $\begin{array}{ll}16.1 & (1.92) \\
4.55 & (2.64) \\
\end{array}$ \\
\hline $\begin{array}{l}\text { Mean overall measure of maternal warmth } \\
\text { (min, max, SD) } \\
\text { Mean overall measure of maternal criticism } \\
\text { (min, max, SD) }\end{array}$ & $\begin{array}{l}1.43 \\
\quad(0,3,0.87) \\
1.74 \\
\quad(0,4,0.91)\end{array}$ \\
\hline
\end{tabular}

The lowest $p$-value associations for each candidate gene are listed in table 4. At a nominal significance level of 0.01 , we found associations at the following ADHD candidate genes: ADRA1A, ADRA1B, ADRA2C, ARRB1, DBH, DDC, DRD3, FADS2, HTR2A, HTR3B, SLC6A1, SLC6A2, SLC6A3, SLC6A4, SLC9A9, SYT1, TPH1, and TPH2. One association in SLC6A1, rs9990174, was significant after adjusting for the comparisons among the 2 phenotypes, 4 environmental variables, and all of the candidate gene SNPs $\left(p\right.$-value $\left.=5.91 \times 10^{-6}\right)$.

\section{GXE interaction found in the absence of} genetic main effects: There were also nominally significant $G \times$ Es found without main genetic effect $(p>0.05)$. A summary of these findings with an interaction $p$ value $<0.001$ are listed in table 5 . Nineteen of these related to $C D$ while only 6 related to ADHD severity. A number of these were in genes previously associated with psychiatric disorders thought unrelated to ADHD. For instance, rs10974610 located in 9p24 in an intronic region of neuronal/epithelial high affinity glutamate transporter (SLC1A1) and rs17746658, located in an intronic region of Neuregulin-3 (NRG3) which were both implicated in $G \times E$ for $C D$ have been implicated in the pathophysiology of several psychiatric disorders. 
Table 2:

A Summary of the Interaction association p-values less than $10^{-5}$ using total ADHD symptoms as the phenotype

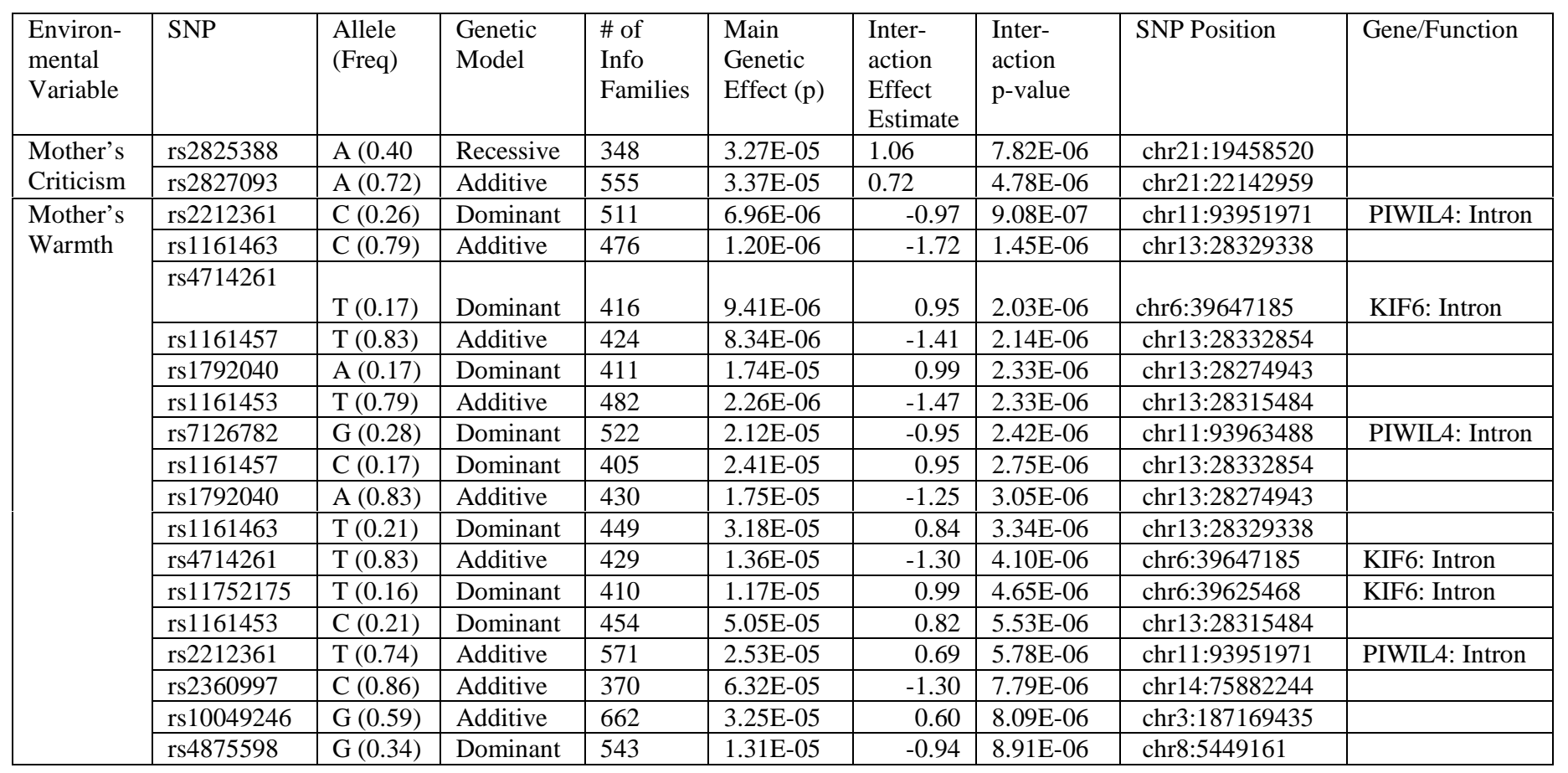

Table 3:

A Summary of the Interaction association p-values less than $10^{-5}$ using total CD symptoms as the phenotype

\begin{tabular}{|c|c|c|c|c|c|c|c|c|c|}
\hline & SNP & $\begin{array}{l}\text { Allele } \\
\text { (Freq) }\end{array}$ & $\begin{array}{l}\text { Genetic } \\
\text { Model }\end{array}$ & $\begin{array}{l}\text { No. } \\
\text { Inform. } \\
\text { Families }\end{array}$ & $\begin{array}{l}\text { Main } \\
\text { Genetic } \\
\text { Effect (p) }\end{array}$ & $\begin{array}{l}\text { Inter- } \\
\text { action } \\
\text { Effect } \\
\text { Estimate }\end{array}$ & $\begin{array}{l}\text { Inter- } \\
\text { action } \\
\text { p-value }\end{array}$ & SNP Position & Gene/Function* \\
\hline \multirow{7}{*}{$\begin{array}{l}\text { Mother's } \\
\text { Criticism }\end{array}$} & rs893971 & $\mathrm{C}(0.40)$ & Dominant & 482 & $7.54 \mathrm{E}-06$ & 1.23 & $3.57 \mathrm{E}-06$ & chr4:89422694 & PPM1K: Intron \\
\hline & rs719593 & $\mathrm{T}(0.86)$ & Additive & 373 & $6.90 \mathrm{E}-05$ & -2.05 & $4.83 \mathrm{E}-06$ & chr2:41858501 & \\
\hline & rs4321143 & $\mathrm{G}(0.28)$ & Dominant & 524 & 0.000135 & 1.13 & $6.57 \mathrm{E}-06$ & chr15:93957372 & \\
\hline & rs893971 & $\mathrm{T}(0.60)$ & Additive & 634 & $6.46 \mathrm{E}-06$ & -1.15 & $6.88 \mathrm{E}-06$ & chr4:89422694 & PPM1K: Intron \\
\hline & rs7162535 & $\mathrm{C}(0.28)$ & Dominant & 522 & 0.00014 & 1.12 & 7.04E-06 & chr15:93959602 & \\
\hline & rs16880441 & $\mathrm{G}(0.08)$ & Dominant & 230 & 7.37E-05 & 1.63 & $8.56 \mathrm{E}-06$ & chr6:89032696 & \\
\hline & rs17116334 & $\mathrm{T}(0.16)$ & Dominant & 392 & $2.28 \mathrm{E}-05$ & 1.30 & $8.99 \mathrm{E}-06$ & chr11:113466972 & ZBTB16: Intron \\
\hline \multirow{11}{*}{$\begin{array}{l}\text { Mother's } \\
\text { Warmth }\end{array}$} & rs13188771 & $\mathrm{A}(0.17)$ & Recessive & 83 & 0.008 & -4.24 & $1.70 \mathrm{E}-06$ & chr5:100976194 & \\
\hline & rs6500744 & $\mathrm{C}(0.53)$ & Additive & 648 & $3.65 \mathrm{E}-05$ & 0.91 & $2.54 \mathrm{E}-06$ & chr16:6053662 & A2BP1: Intron \\
\hline & rs1789891 & $\mathrm{A}(0.14)$ & Dominant & 346 & $3.44 \mathrm{E}-05$ & 1.47 & $3.17 \mathrm{E}-06$ & chr4:100469442 & ADH1C: Downstream \\
\hline & rs1229863 & $\mathrm{T}(0.14)$ & Dominant & 350 & $4.57 \mathrm{E}-05$ & 1.45 & $3.77 \mathrm{E}-06$ & chr4:100471409 & ADH1C: Downstream \\
\hline & rs332034 & $\mathrm{A}(0.85)$ & Additive & 382 & $6.55 \mathrm{E}-05$ & 1.05 & $5.77 \mathrm{E}-06$ & chr8:8754417 & MFHAS1: Intron \\
\hline & rs9990174 & $\mathrm{T}(0.33)$ & Recessive & 257 & $3.56 \mathrm{E}-05$ & -2.52 & $5.91 \mathrm{E}-06$ & chr3:11015439 & SLC6A1: Intron \\
\hline & rs2395528 & $\mathrm{T}(0.23)$ & Dominant & 486 & $4.94 \mathrm{E}-05$ & -1.46 & $6.17 \mathrm{E}-06$ & chr10:79770867 & \\
\hline & rs2282301 & $\mathrm{A}(0.23)$ & Recessive & 139 & $4.90 \mathrm{E}-06$ & 2.88 & $7.01 \mathrm{E}-06$ & chr1:154135249 & RIT1: Downstream \\
\hline & rs17664267 & $\mathrm{T}(0.19)$ & Dominant & 426 & $2.24 \mathrm{E}-05$ & 1.39 & $7.10 \mathrm{E}-06$ & chr18:39062796 & \\
\hline & rs8073783 & $\mathrm{C}(0.49)$ & Dominant & 417 & $1.56 \mathrm{E}-05$ & -1.76 & $7.81 \mathrm{E}-06$ & chr17:48592940 & \\
\hline & rs604381 & $\mathrm{A}(0.32)$ & Dominant & 500 & $4.24 \mathrm{E}-05$ & 1.26 & $8.29 \mathrm{E}-06$ & chr2:37830521 & \\
\hline
\end{tabular}

* A blank indicates that the SNP is not within a gene 
Table 4. The most significant interaction associations at alpha $=0.01$ or better for the $a$ priori specified ADHD candidate genes

\begin{tabular}{|c|c|c|c|c|c|c|c|c|c|}
\hline \multirow[t]{3}{*}{ Candidate Gene } & \multirow{3}{*}{$\begin{array}{l}\text { Number of SNPs per } \\
\text { Gene }\end{array}$} & \multicolumn{8}{|c|}{ Number of associated test by phenotype } \\
\hline & & \multicolumn{4}{|c|}{ ADHD symptom Count } & \multicolumn{4}{|c|}{ CD symptom Count } \\
\hline & & Criticism & SNP & Warmth & SNP & Criticism & SNP & Warmth & SNP \\
\hline ADRA1A & 47 & 0.00277 & rs 10503800 & & & & & & \\
\hline ADRA1B & 18 & & & & & 0.0023 & rs17455628 & & \\
\hline ADRA2C & 2 & 0.0066 & rs7692883 & & & & & & \\
\hline ARRB1 & 2 & 0.00186 & rs687652 & & & & & & \\
\hline DBH & 21 & 0.0044 & rs2797851 & 0.0021 & rs2797851 & 0.0098 & rs1611115 & & \\
\hline DDC & 24 & $\begin{array}{l}0.000998 \\
0.0034 \\
0.0013 \\
0.0061 \\
0.0062 \\
0.0035\end{array}$ & $\begin{array}{l}\text { rs11974297 } \\
\text { rs11489734 } \\
\text { rs7804365 } \\
\text { rs7807335 } \\
\text { rs921451 } \\
\text { rs978784 }\end{array}$ & $\begin{array}{l}0.000587 \\
0.0047 \\
0.0099 \\
0.0078 \\
0.0064 \\
0.0049 \\
0.0033 \\
\end{array}$ & $\begin{array}{l}\text { rs } 7804365 \\
\text { rs } 10499694 \\
\text { rs11238133 } \\
\text { rs11974297 } \\
\text { rs } 1470750 \\
\text { rs17634958 } \\
\text { rs } 4602840 \\
\end{array}$ & & & & \\
\hline DRD3 & 15 & & & & & & & $\begin{array}{l}0.00495 \\
0.0099 \\
\end{array}$ & $\begin{array}{l}\text { rs3773678 } \\
\text { rs324032 }\end{array}$ \\
\hline FADS2 & 9 & 0.00778 & rs 174626 & & & 0.0056 & rs174570 & & \\
\hline HTR2A & 40 & & & $\begin{array}{l}0.00091 \\
0.001 \\
0.0036 \\
\end{array}$ & $\begin{array}{l}\text { rs1923886 } \\
\text { rs6561333 } \\
\text { rs7330636 }\end{array}$ & $\begin{array}{l}0.0042 \\
0.0077\end{array}$ & $\begin{array}{l}\text { rs1885884 } \\
\text { rs1002513. }\end{array}$ & & \\
\hline HTR3B & 10 & & & & & 0.0019 & rs4936286 & & \\
\hline SLC6A1 & 23 & & & & & $\begin{array}{l}0.001 \\
0.0067 \\
\end{array}$ & $\begin{array}{l}\mathrm{rs} 1710892 \\
\mathrm{rs} 1919075 \\
\end{array}$ & 5.91E-06 & \\
\hline SLC6A2 & 27 & & & & & & & 0.009 & rs16955708 \\
\hline SLC6A3 & 13 & 0.0056 & rs3863145 & & & 0.0065 & rs458334. & 0.00144 & rs2550936 \\
\hline SLC6A4 & 6 & & & 0.008 & rs2020939 & & & & \\
\hline SLC9A9 & 181 & 0.0099 & rs11916000 & $\begin{array}{l}0.00063 \\
0.0021 \\
0.0091 \\
0.0064 \\
0.0025 \\
0.004 \\
0.0015 \\
\end{array}$ & $\begin{array}{l}\text { rs } 11721078 \\
\text { rs } 11916000 \\
\text { rs } 16854336 \\
\text { rs } 1868183 \\
\text { rs } 1875463 \\
\text { rs } 4839595 \\
\text { rs } 746351 \\
\end{array}$ & $\begin{array}{l}0.0024 \\
0.0026 \\
0.006 \\
0.004 \\
0.0047\end{array}$ & $\begin{array}{l}\text { rs2293328 } \\
\text { rs11916000 } \\
\text { rs1242076 } \\
\text { rs1554671 } \\
\text { rs9289668 }\end{array}$ & $\begin{array}{l}0.0054 \\
0.0065 \\
0.0083 \\
0.0057\end{array}$ & $\begin{array}{l}\text { rs11916000 } \\
\text { rs9289667 } \\
\text { rs9332458 } \\
\text { rs9848371 }\end{array}$ \\
\hline SNAP25 & 29 & & & 0.0092 & rs6133855 & & & & \\
\hline SYT1 & 16 & & & 0.0066 & rs7300645 & & & & \\
\hline TPH1 & 7 & & & & & 0.00396 & rs623580 & & \\
\hline ТPH2 & 19 & & & & & & & $\begin{array}{l}0.000499 \\
0.0038 \\
0.0011 \\
\end{array}$ & $\begin{array}{l}\text { rs11179050 } \\
\text { rs1487275 } \\
\text { rs4488237 }\end{array}$ \\
\hline
\end{tabular}




\section{DISCUSSION:}

Environmental exposures may moderate the degree of association between genetic markers and ADHD, its severity and its comorbidity [Thapar et al., 2007]. Therefore studying the interaction between environmental exposures and multiple genetic markers from across the genome can facilitate the search for novel genes and help elucidate underlying pathogenic mechanisms. The current analysis using a quantitative phenotype for ADHD severity and CD comorbidity as well as environmental measures of maternal warmth and criticism in a GXE interaction GWAS analysis, represents the first attempt at such an a analysis. No GXE interactions met genome-wide significance after adjusting for all comparisons; however, there are several findings of potential interest among the association tests with the lowest $p$-values. In general a number of aspects of the results were noteworthy.

First, the results highlight the possible putative role that the family environment may have as a moderator of genetic effects in ADHD. Previous research has largely focused on biologically mediated effects such as those associated with prenatal exposure to nicotine [Khan et al., 2003] and alcohol [Brookes et al., 2006b]. Specifying the biological mechanism that might be responsible for gene $x$ social environment interactions is beyond the scope of the current paper. Future research should focus on fundamental mechanisms underpinning the environmental factors that regulate gene expression. For instance, the hypothesis that adverse social environments (here marked by maternal hostility) may 'switchoff', or socially benign environments 'switch-on' genetic effects [Peedicayil, 2007] is a hypothesis worth exploring further. While almost nothing is known empirically about the power of the family environment to impinge on gene expression within the human infant, recent animal models suggest that such effects may occur through epigenetic effects such as DNA methylation [Parent et al., 2005; Diorio and Meaney, 2007]. However, for these effects to account for the current finding would require the marker of environmental adversity, in this case an interview-based measure of $\mathrm{EE}$, to be indexing a broadly based, stable and powerful social influence of long-standing, that can induce fundamental changes in gene expression. If this were the case then chronic exposure to these sorts of histories of aversive family interactions could conceivably have the potency to alter gene expression.

Second, we provide preliminary evidence that $\mathrm{G} \times \mathrm{E}$ interactions may occur both in the presence or the absence of a genetic main effect. This is important as it clearly suggests that in addition to potentially facilitating the understanding of the pathophysiology of ADHD and related conditions, studying $G \times E$ interactions may have the potential to identify novel genes in its own right, most likely by helping to partition the genetic heterogeneity in the sample. While further research is required to elucidate the specifics of these effects, one hypothesis worth exploring is that there are environmentally defined sub-groups with a distinctive pattern of genetic risk.

Third, possible $G \times E$ effects were observed for both ADHD severity and conduct disorder comorbidity, although none of these findings survived the multiple testing correction. Previous studies of ADHD and EE have focused on conduct disorder as the primary outcome measure and have suggested that EE may do little to alter the fundamental expression of ADHD. The current results suggest, in contrast, that maternal expressions of warmth and criticism may 
act together with genetic factors to alter the severity of ADHD. Given the cross sectional nature of the data in the current study it is impossible to disentangle the direction of causation, to say whether criticism and low warmth combine with specific genes to increase the severity of ADHD, or whether children with high levels of ADHD who carry specific alleles elicit high levels of EE from parents. In this regard it is interesting that the relative proportion of nominal effects for ADHD severity and CD was different for GXE effects that were and were not accompanied by genetic main effects. There were proportionately fewer GXE effects for ADHD severity in the case of no genetic main effects. One possible interpretation of this is that for ADHD severity variations in EE typically act to 'fine tune' genetic main effects while for $C D$ the EE levels mark a distinctive genetic subtype.

Fourth, the two components of $\mathrm{EE}$ measured may play different and distinctive roles in relation to the two outcomes. First, although both warmth and criticism were implicated for each phenotype, these two elements may be interacting with different genes. Second, levels of warmth appear a more powerful marker of the moderators of ADHD severity, with only a small number of interactions with criticism reaching nominal significance for this outcome. For conduct disorder, both warmth and criticism were equally likely to be implicated. These results highlight the value of looking at warmth and criticism separately when exploring GXE interactions.

The data relating to individual genes are also of some note. Of the 37 uncorrected interaction $p$-values less than $10^{-5}$, the most compelling finding is the interaction of rs9990174 and CD symptoms with a $p$-value of $5.19 \times 10^{-6}$.
Rs9990174 is in an intronic region of solute carrier family 6 , member 1 (SLC6A1, encoding the gamma-aminobutyric acid (GABA) transporter) located on 3p25-p24. This is a candidate gene that was selected a priori by our investigators because, early in development, it plays a role in both brain maturation and later functions as a neurotransmitter [Kandel et al., 1991]. There are also two additional SNPs (rs1710892, rs1919075) in SLC6A1 that interact with mother's criticism ( $p$-values < 0.01) that are associated with $C D$ symptoms. Of the recent GWAS analyses using the IMAGE data, SLC6A1 emerges in the gene by environment analyses more strongly that using any other phenotype or analytic method.

There were several notable nominally significant associations among the list of ADHD candidate genes. Given the number of SNPs at each gene, DDC had the largest percentage of nominally significant associations ( $p$-value $<0.01$ ) among the candidate genes with 11 of the 24 SNPs in DDC having an association p-value less than 0.01 . All of these associations were observed with the ADHD symptom counts and both environmental measures. SLC9A9 had association $p$-values $<0.01$ for all phenotypes and environmental measures. This is not surprising; however, as 181 SNPs were genotyped in SLC9A9 to characterize the gene and therefore one would expect association $p$-values less than 0.01 by chance. Several of the neurotransmitter transporters (SLC6A1, SLC6A2, SLC6A3, SLC6A4, SLC6A6, and SLC9A9) have gene by environment interaction $p$-values less than 0.01, suggesting that these transporters may have important interaction effects.

Turning to the $G \times E$ effects that occurred without genetic main effects as mentioned above these are predominantly for CD. Rs10974610 is located in 9p24 in an intronic region of neuronal/epithelial 
high affinity glutamate transporter (SLC1A1) and was found to have a nominally significant GXE interaction with CD symptom count and overall maternal warmth. SLC1A1 has been implicated in the pathophysiology of several psychiatric disorders including schizophrenia, obsessive compulsive disorder, and bipolar disorder and is therefore a plausible candidate gene for ADHD and $C D$. An associations study found this gene and schizophrenia to be associated [Nudmamud-Thanoi et al., 2007] and microarray data suggest that there is decreased transcriptional expression among individuals diagnosed with schizophrenia [McCullumsmith and Meador-Woodruff, 2002]. The chromosomal region containing this gene has also been identified in a linkage analysis of early-onset obsessive-compulsive disorder [Veenstra-Vander Weele et al., 2001]. Finally, a translocation in SLC1A1 was found to segregate with bipolar disorder [Baysal et al., 1998]. SLC1A1 presents a good biologic candidate for $C D$ because it is a neuronal and epithelial glutamate transporter. Although is has been studied in relation to other psychiatric disorders, currently there is no research of this gene in relation to CD. Rs17746658, located in an intronic region of neuroregulin-3 (NRG3), was associated in a gene by environment interaction with $C D$ and overall maternal criticism. Although neuregulin-1 has most commonly been associated with psychiatric disorders, NRG3 has also been implicated in several psychiatric disorders, most notably schizophrenia, and has also been found to have gene-gene interaction with other neuroregulin genes [Benzel et al., 2007]. Of the GWAS studies with the IMAGE data to date, no other phenotypes have identified SNPs in either SLC1A1 or NRG3 as possible candidate genes to follow-up in replication samples [Neale et al. in press; Lasky-Su et al., in press]. Although these SNPs were identified by having low nominal $p$-values, their confirmation requires replication. Clearly these findings are just preliminary and future replications are the only way to verify or refute.

In summary the current GWAS analysis provides some initial evidence, at nominal levels of significance, for the role of parental EE as a moderator of novel genetic effects in relation to both ADHD severity and the presence of comorbid conduct disorder. Of particular note are the effects that occur without a genetic main effect typically related to $C D$ that implicate previous candidates for psychiatric disorders and may be related to an ADHD subtype susceptible to social environmental influence for $C D$. These effects need to replicated in larger independent samples and to be explored in more detail using a range of different measures on mother's attitudes and mother child interaction.

\section{REFERENCES:}

Baker BL, Heller TL, Henker B. 2000. Expressed emotion, parenting stress, and adjustment in mothers of young children with behaviour problems. J Child Psychol Psychiatry 41: 907-915.

Baysal BE, Potkin SG, Farr JE, Higgins MJ, Korcz J, Gollin SM, James MR, Evans GA, Richard CW, 3rd. 1998. Bipolar affective disorder partially co-segregates with a balanced $t(9 ; 11)$ (p24;q23.1) chromosomal translocation in a small pedigree. Am J Med Genet 81:81-91.

Becker K, El-Faddagh $\mathrm{M}$, Schmidt $\mathrm{MH}$, Esser G, Laucht M. 2008. Interaction of dopamine transporter genotype with prenatal smoke exposure on ADHD symptoms. J Pediatr 152:263-269.

Benzel I, Bansal A, Browning BL, Galwey NW, Maycox PR, McGinnis R, Smart D, St Clair D, Yates P, Purvis I. 2007. Interactions among genes in the ErbBneuroregulin signaling network are 
associated with increased susceptibility to schizophrenia. Behav Brain Funct 3:31.

Brookes K, Xu X, Chen W, Zhou K, Neale B, Lowe N, Anney R, Franke B, Gill M, Ebstein R, Buitelaar J, Sham P, Campbell $D$, Knight J, Andreou P, Altink M, Arnold R, Boer F, Buschgens C, Butler L, Christiansen $\mathrm{H}$, Feldman L, Fleischman K, Fliers E, Howe-Forbes R, Goldfarb A, Heise A, Gabriels I, Korn-Lubetzki I, Marco R, Medad S, Minderaa R, Mulas $F$, Muller $U$, Mulligan $A$, Rabin $K$, Rommelse N, Sethna V, Sorohan J, Uebel H, Psychogiou L, Weeks A, Barrett R, Craig I, Banaschewski T, Sonuga-Barke E, Eisenberg J, Kuntsi J, Manor I, McGuffin Pm, Miranda A, Oades RD, Plomin R, Roeyers $H$, Rothenberger A, Sergeant J, Steinhausen HC, Taylor E, Thompson M, Faraone SV, Asherson P, Johansson L. 2006a. The analysis of 52 candidate genes in DSM-VI combined subtype attention deficit hyperactivity disorder: association signals in DRD4, DAT1 and 16 other genes. Mol Psych 11:934-953.

Brookes KJ, Mill J, Guindalini C, Curran S, $\mathrm{Xu} \mathrm{X}$, Knight J, Chen CK, Huang YS, Sethna V, Taylor E, Chen W, Breen G, Asherson P. 2006b. A common haplotype of the dopamine transporter gene associated with attentiondeficit/hyperactivity disorder and interacting with maternal use of alcohol during pregnancy. Arch Gen Psychiatry 63:74-81.

Caspi A, Sugden K, Moffitt TE, Taylor A, Craig IW, Harrington $\mathrm{H}$, McClay J, Mill J, Martin J, Braithwaite A, Poulton R. 2003. Influence of life stress on depression: moderation by a polymorphism in the 5-HTT gene. Science 301:386-389.

Caspi A, Langley K, Milne B, Moffitt TE, O'Donovan $\mathrm{M}$, Owen MJ, Tomas MP, Poulton R, Rutter M, Taylor A, Williams
B, Thapar A. 2008. A replicated molecular genetic basis for sub-typing antisocial behavior in children with attention-deficit/hyperactivity disorder. Arch Gen Psychiatry 5:203-210.

Crosbie J, Perusse D, Barr CL, Schachar RJ. 2008. Validating psychiatric endophenotypes: Inhibitory control and attention deficit hyperactivity disorder. Neurosci Biobehav Rev 32: 40-55.

Daley D, Sonuga-Barke E, Thompson M. 2003. Assessing expressed emotion in mothers of preschool AD/HD children: Psychometric properties of a modified speech sample. Br J Clin Psychol 42: 5367.

Diorio J, Meaney MJ. 2007. Maternal programming of defensive responses through sustained effects on gene expression. J Psychiat Neurosci 32:275284.

Faraone SV, Perlis RH, Doyle AE, Smoller JW, Goralnick JJ, Holmgren MA, Sklar P. 2005. Molecular genetics of attentiondeficit/hyperactivity disorder. Biol Psychiatry 57:1313-1323.

Johnston C, Mash EJ. 2001. Families of children with attention-deficit/ hyperactivity disorder: review and recommendations for future research. Clin Child Fam Psychol Rev 4:183-207.

Kandel ER, Schwartz JH, Jessell TM, editors. 1991. Principles of Neural Science. 3rd Ed. ed. Norwalk, Conn: Appleton \& Lange. 1-1135 pp.

Kahn RS, Khoury J, Nichols WC, Lanphear BP. 2003. Role of dopamine transporter genotype and maternal prenatal smoking in childhood hyperactiveimpulsive, inattentive, and oppositional behaviors. J Pediatrics, 143:104-110.

Lange C, DeMeo D, Silverman EK, Weiss ST, Laird NM. 2004. PBAT: tools for family-based association studies. Am J Hum Genet 74:367-369. 
Li DW, Sham PC, Owen MJ, He L. 2006. Meta-analysis shows significant association between dopamine system genes and attention deficit hyperactivity disorder (ADHD). Hum Mol Genet 15: 2276-2284.

McCullumsmith RE, Meador-Woodruff JH. 2002. Striatal excitatory amino acid transporter transcript expression in schizophrenia, bipolar disorder, and major depressive disorder. Neuropsychopharmacology 26:368-375.

Mick E, Faraone SV. 2008. Genetics of attention deficit hyperactivity disorder. Child Adolesc Psychiatry Clin N Am 17:261-84, vii-viii.

Neuman RJ, Lobos E, Reich W, Henderson CA, Sun LW, Todd RD. 2007. Prenatal smoking exposure and dopaminergic genotypes interact to cause a severe ADHD subtype. Biol Psychiatry 61:13201328.

Nudmamud-Thanoi S, Piyabhan $P$, Harte MK, Cahir M, Reynolds GP. 2007. Deficits of neuronal glutamatergic markers in the caudate nucleus in schizophrenia. J Neural Transm Suppl: 281-5.

Oades RD. 2002. Dopamine may be 'hyper' with respect to noradrenaline metabolism, but 'hypo' with respect to serotonin metabolism in children with attention-deficit hyperactivity disorder. Behav Brain Res 130:97-102.

Parent C, Zhang TY, Caldji C, Bagot R, Champagne FA, Pruessner J, Meaney MJ. 2005. Maternal care and individual differences in defensive responses. Current Directions Psychol Science 14:229-233.

Peedicayil J. 2007. The role of epigenetics in mental disorders. Indian J Med Res 126:105-111.

Pfiffner L, McBurnett K, Rathouz P, Judice S. 2005. Family correlates of oppositional and conduct disorders in children with Attention Deficit Hyperactivity Disorder. J Abnorm Child Psych 33: 551-563.

Pressman LJ, Loo SK, Carpenter EM, Asarnow JR, Lynn D, McCracken JT, McGough JJ, Lubke GH, Yang $\mathrm{MH}$, Smalley SL (2006). Relationship of family environment and parental psychiatric diagnosis to impairment in ADHD. J Am Acad Child Adolesc Psychiatry 45: 346-354

Propper C, Willoughby $M$, Halpern CT, Carbone MA, Cox M 2007. Parenting quality, DRD4, and the prediction of externalizing and internalizing behaviors in early childhood. Dev Psychobiol 49: 619-632.

Psychogiou L, Daley D, Thompson M, Sonuga-Barke E. 2007. Mothers' Expressed Emotion toward their schoolaged sons: Associations with child and maternal symptoms of psychopathology. Eur Child Adolesc Psychiatry, 16: 458-464.

Rutter M, Moffitt TE, Caspi A. 2006. Geneenvironment interplay and psychopathology: multiple varieties but real effects. J Child Psychol Psychiatry 47: 226-261.

Schachar R, Taylor E, Wieselberg, M, Thorley G, Rutter M. 1987. Changes in family function and relationships in children who respond to methylphenidate. J Am Acad of Child Adolesc Psychiatry 26: 728-732.

Sonuga-Barke EJS, Buitelaar J, Bitsakou P, Baeyens D, Buschgens C, Chen W, Christiansen $\mathrm{H}$, Eisenberg J, Kuntsi J, Manor I, Melia A, Mulligan A, Rommelse N, Müller UC, Uebel $H$, Banaschewski T, Ebstein R, Franke B, Gill M, Miranda A, Oades RD, Roeyers $H$, Rothenberger A, Sergeant J, Steinhausen HC, Thompson M, Taylor E, Asherson P, Faraone SV. 2008. 
Intelligence in DSM-IV Combined Type Attention-Deficit/Hyperactivity

Disorder is not predicted by either Dopamine Receptor/Transporter Genes or other previously identified Risk Alleles for Attention-Deficit/ Hyperactivity Disorder. Am J Med Gen 147B:316-319.

Taylor E, Chadwick O, Heptinstall E, Danckaerts M. 1996. Hyperactivity and conduct problems as risk factors for adolescence development. J Am Acad Child Adolesc Psychiatry 35: 1312-1226.

Taylor E, Everitt B, Thorley G, Schachar R, Rutter M, Wieselberg M. 1986a. Conduct disorder and hyperactivity: II. A cluster analytic approach to the identification of a behavioural syndrome. Br J Psychiatry 149:768-777.

Taylor E, Schachar R, Thorley G, Wieselberg M. 1986b. Conduct disorder and hyperactivity: I. Separation of hyperactivity and antisocial conduct in British child psychiatric patients. $\mathrm{Br} \mathrm{J}$ Psychiatry 149:760-7.

Thapar A, Langley K, Asherson P, Gill M. 2007. Gene-environment interplay in attention-deficit hyperactivity disorder and the importance of a developmental perspective. Br J Psychiatry 190:1-3.

Van ljzendoorn $\mathrm{MH}$, BakermansKranenburg MJ 2006. DR4 7-repeat polymorphism moderates the association between maternal unresolved loss or trauma and infant disorganization. Attachment Human Dev 8: 291-307.

Vansteelandt S, Demeo DL, Lasky-Su J, Smoller JW, Murphy AJ, McQueen M, Schneiter K, Celedon JC, Weiss ST, Silverman EK, Lange C. 2008. Testing and Estimating Gene-Environment Interactions in Family-Based Association Studies. Biometrics 64:458467.

Vaughn C, Leff J. 1976. The measurement of Expressed Emotion in families of psychiatric patients. $\mathrm{Br} \mathrm{J}$ Soc Clin Psychol 15: 157-165.

Veenstra-VanderWeele J, Kim SJ, Gonen D, Hanna GL, Leventhal BL, Cook EH, Jr. 2001. Genomic organization of the SLC1A1/EAAC1 gene and mutation screening in early-onset obsessivecompulsive disorder. Mol Psychiatry 6:160-7. 
Table 5: A Summary of the Interaction association $p$-values less than 0.001 and no main genetic effect $(p>0.05)$ using total ADHD and CD symptoms as the phenotype.

\begin{tabular}{|c|c|c|c|c|c|c|c|c|c|c|}
\hline $\begin{array}{l}\text { Environmental } \\
\text { Variable and } \\
\text { Phenotype }\end{array}$ & SNP & $\begin{array}{l}\text { Allele } \\
\text { (Freq) }\end{array}$ & Model & $\begin{array}{l}\text { Info } \\
\text { Fam }\end{array}$ & $\begin{array}{l}\text { Main } \\
\text { Genetic } \\
\text { Effect (p) }\end{array}$ & $\begin{array}{l}\text { Interaction } \\
\text { Effect } \\
\text { Estimate }\end{array}$ & $\begin{array}{l}\text { Interaction p- } \\
\text { value }\end{array}$ & SNP position & Gene(s) & Role \\
\hline \multirow{8}{*}{$\begin{array}{l}\text { Mother's } \\
\text { Warmth/CD } \\
\text { Symptom Count }\end{array}$} & rs10974610 & $\mathrm{G}(0.12)$ & Recessive & 44 & 0.061 & -5.90 & 0.00021812 & chr9:4530588 & SLC1A1 & Intron \\
\hline & rs 1871437 & $\mathrm{~T}(0.10)$ & Recessive & 23 & 0.105 & -12.66 & 0.000622013 & chr15:90536919 & & \\
\hline & rs10980865 & $\mathrm{C}(0.12)$ & Recessive & 36 & 0.063 & -8.2 & 0.000712936 & chr9:113112797 & & \\
\hline & rs17714301 & A $(0.13)$ & Recessive & 44 & 0.071 & -18.81 & 0.000809531 & chr19:61260662 & NALP5 & Intron \\
\hline & rs 1335204 & $\mathrm{C}(0.10)$ & Recessive & 35 & 0.111 & -12.57 & 0.000819165 & chr10:25946497 & & \\
\hline & rs12776431 & C 0.10) & Recessive & 35 & 0.111 & -12.57 & 0.000819179 & chr10:25937098 & GPR158 & Downstream \\
\hline & rs2921007 & $\mathrm{T}(0.13)$ & Recessive & 58 & 0.132 & -30.50 & 0.000890434 & chr8:8269681 & & \\
\hline & rs12108098 & $\mathrm{T}(0.12)$ & Recessive & 42 & 0.125 & -19.27 & 0.000978051 & chr3:61487959 & & \\
\hline \multirow{8}{*}{$\begin{array}{l}\text { Mother's } \\
\text { Criticism/CD } \\
\text { Symptom Count }\end{array}$} & rs6889324 & $\mathrm{A}(0.11)$ & Recessive & 36 & 0.064 & -6.27 & 0.000193258 & chr5:139420647 & & \\
\hline & rs16960350 & $\mathrm{C}(0.13)$ & Recessive & 48 & 0.053 & -3.00 & 0.000600393 & $\operatorname{chr17:62321449}$ & CACNG5 & Downstream \\
\hline & rs12603171 & $\mathrm{T}(0.14)$ & Recessive & 61 & 0.071 & -5.61 & 0.00073312 & $\operatorname{chr17:78566042}$ & B3GNTL1 & Intron \\
\hline & rs17127947 & $\mathrm{G}(0.20)$ & Recessive & 130 & 0.062 & -6.07 & 0.000750021 & chr11:123282512 & OR8D4 & Coding exon \\
\hline & rs17127950 & $\mathrm{G}(0.21)$ & Recessive & 128 & 0.063 & -6.04 & 0.000782704 & chr11:123282622 & OR8D4 & Coding exon \\
\hline & rs17746658 & $\mathrm{C}(0.09)$ & Recessive & 30 & 0.090 & -15.00 & 0.000832163 & chr10:84561249 & NRG3 & Intron \\
\hline & rs4422732 & $\mathrm{G}(0.14)$ & Recessive & 75 & 0.067 & -4.52 & 0.000891919 & chr8:82966209 & & \\
\hline & rs6877423 & $\mathrm{A}(0.11)$ & Recessive & 33 & 0.122 & -5.25 & 0.000975995 & chr5:139418290 & & \\
\hline
\end{tabular}




\begin{tabular}{|c|c|c|c|c|c|c|c|c|c|c|}
\hline & rs847971 & $\mathrm{G}(0.09)$ & Recessive & 29 & 0.053 & -7.42 & 0.000982706 & chr7:12448530 & & \\
\hline & rs290439 & $\mathrm{G}(0.19)$ & Recessive & 106 & 0.080 & -2.86 & 0.00081694 & chr20:52116797 & BCAS1 & Intron \\
\hline $\begin{array}{l}\text { Mother's } \\
\text { Warmth/ADHD } \\
\text { Symptom Count }\end{array}$ & rs17492765 & $\mathrm{T}(0.16)$ & Recessive & 73 & 0.056 & -2.30 & 0.000188326 & chr15:93842747 & & \\
\hline \multirow{4}{*}{$\begin{array}{l}\text { Mother's } \\
\text { Criticism/ADHD } \\
\text { Symptom Count }\end{array}$} & rs1590106 & $\mathrm{G}(0.12)$ & Recessive & 52 & 0.079 & -3.17 & 0.000352921 & chr18:66841766 & & \\
\hline & rs11609420 & A $(0.25)$ & Recessive & 164 & 0.062 & -1.07 & 0.000798172 & chr12:93676075 & & \\
\hline & rs2476509 & $\mathrm{G}(0.08)$ & Recessive & 35 & 0.089 & -4.48 & 0.000877486 & chr13:21733572 & & \\
\hline & rs10865184 & $\mathrm{G}(0.83)$ & Additive & 423 & 0.073 & 0.54 & 0.00093328 & chr2:42749320 & MTA3 & Intron \\
\hline
\end{tabular}

